\title{
First trimester prenatal diagnosis and detection of carriers of haemophilia A using the linked DNA probe DX13
}

\author{
R M WINTER, K HARPER, E GOLDMAN, R S MIBASHAN, R C WARREN, \\ C H RODECK, R J A PENKETH, R H T WARD, R M HARDISTY, M E PEMBREY
}

\begin{abstract}
Although the use of a gene specific deoxyribonucleic acid (DNA) probe is the method of choice for detecting carriers of genes for rare genetic disorders, there will always be families in which such probes cannot be used because key subjects are not informative for restriction fragment length polymorphisms in or around the gene. In these cases closely linked DNA markers have to be used.

An $X$ chromosome specific DNA probe, DX13, which is closely linked to the haemophilia $\mathbf{A}$ locus on the $\mathbf{X}$ chromosome, was used for early prenatal diagnosis in two cases and to detect carriers in a series of nine possible heterozygote women. The first reported crossover between DX13 and the factor VIII:C locus was observed in this study.

There are complexities inherent in using any linked DNA probe for assignment of genes, but such techniques are clinically important.
\end{abstract}

\footnotetext{
Division of Inherited Metabolic Disease, Clinical Research Centre, Northwick Park Hospital, Harrow, Middlesex

R M WINTER, BSC, MRCP, consultant clinical geneticist

Institute of Child Health, London WC1

K HARPER, FIMLS, research assistant, Mothercare unit of paediatric genetics R M HARDISTY, FRCP, FRCPATH, professor of haematology

$M$ E PEMBREY, MD, FRCP, senior lecturer in paediatric genetics

Haemophilia Centre, Royal Free Hospital, London NW3

E GOLDMAN, $\mathrm{MB}, \mathrm{BCH}$, clinical assistant

King's College School of Medicine and Dentistry, London SE5

R S MIBASHAN, MD, FRCPATH, senior lecturer and consultant in haematology

R C WARREN, MRCOG, research fellow and honorary senior registrar, HarrisBirthright Research Centre for Fetal Medicine

C H RODECK, BSC, MRCOG, director, Harris-Birthright Research Centre for Fetal Medicine

University College Hospital, London WC1

R J A PENKETH, MB, BSC, honorary research assistant, department of genetics and biometry

R H T WARD, FRCOG, consultant gynaecologist and obstetrician

Correspondence to: Dr Winter.
}

\section{Introduction}

Haemophilia A (deficiency of factor VIII) is inherited as an X linked recessive disorder with an incidence at birth of $1-2 / 10000$ boys. ${ }^{12}$ The genetic locus for haemophilia $\mathrm{A}$ is found in band q28 of the $\mathrm{X}$ chromosome. ${ }^{3}$ Tests to detect female carriers based on estimation of amounts of factor VIII:C and factor VIIIR:antigen are only about $80 \%$ accurate ${ }^{4}$ and more reliable tests are needed. Prenatal diagnosis depends on the sampling of fetal blood at 18 weeks' gestation, leading to a late termination of pregnancy in affected cases. ${ }^{5}$ Chorionic villus sampling allows fetal sex to be determined at nine weeks' gestation by analysis of chromosomes. ${ }^{6}$ Deoxyribonucleic acid (DNA) from such samples may also be used to determine fetal $\operatorname{sex}^{7}$ or for prenatal diagnosis of specific diseases provided that the appropriate DNA probes are available. ${ }^{8}$

An X chromosome specific DNA probe, DX13, is closely linked to the haemophilia A locus. ${ }^{9}$ When DNA is digested with the restriction enzyme BglII this probe shows a restriction fragment length polymorphism for which half of women are heterozygous, making DX13 a potentially useful probe for detecting carriers and for prenatal diagnosis, either on its own or in combination with conventional tests.

The factor VIII: $\mathrm{C}$ gene has been cloned and all the coding regions sequenced. ${ }^{10} \mathrm{~A}$ single $\mathrm{BclI}$ restriction fragment length polymorphism has been found in the factor VIII gene, ${ }^{11}$ and both prenatal diagnosis and detection of carriers using this polymorphism have been reported..$^{12}$ In a proportion of women, however, detection of carriers and prenatal diagnosis using the factor VIII:C probe may not be possible as key women in the pedigree may not be heterozygous for the restriction fragment length polymorphism within the gene. In these families back up systems would have to be used. We describe here the use of the DX13 probe to detect carriers and for prenatal diagnosis of haemophilia $A$ in a small consecutive series of cases to emphasise the complexities inherent in using linked probes.

One limitation is that the mother of a fetus at risk, or of a woman seeking to establish whether she is a carrier, has to be heterozygous for the restriction fragment length polymorphism around the linked probe to allow one $\mathrm{X}$ chromosome to be distinguished from the other. If the woman is heterozygous analysis of other family members is necessary to establish which $\mathrm{X}$ chromosome carries the 
haemophilia mutation. Clearly, if a woman is known to have inherited the haemophilia mutation from her mother the restriction enzyme pattern of her father's X chromosome defines which of her $\mathrm{X}$ chromosomes is not carrying the haemophilia mutation, and therefore her linkage phase is known. Deducing the linkage phase, however, can be complicated by new mutations and crossovers or genetic recombination between $\mathrm{X}$ chromosomes during the formation of ova and is made more difficult if key members of the family are unavailable for testing. The closer the marker DNA probe sequence is to the mutation causing the disease the less likely are the two to be separated by crossing over and the more likely are predictions to be correct.

The principles described here are appropriate to the general problem of assignment of genes, using linked DNA probes in any genetic disorder.

\section{Subjects}

Family A was known to both the department of haematology, King's College Hospital, and the haemophilia centre, Royal Free Hospital. Family $B$ was known to the Royal Free Hospital and was referred to the department of obstetrics, University College Hospital, for chorionic villus sampling.

Possible carriers of haemophilia A who could potentially be provided with further information by the use of the DX13 probe were ascertained through the haemophilia centres of the Royal Free Hospital and the Hospital for Sick Children, Great Ormond Street. These subjects were premenopausal women whose appropriate family members were available for examination by the linkage approach. Twenty three mothers of a total of 36 women were tested to see whether they were heterozygous for the DX13 probe.

\section{Methods}

Venous blood samples (about $10 \mathrm{ml}$ ) were collected into edetic acid and the DNA extracted from white cells by standard techniques. ${ }^{14}$ Chorionic villus samples were obtained by the transcervical route under ultrasound guidance. In family $\mathrm{A}$ aspiration biopsy was carried out with a malleable

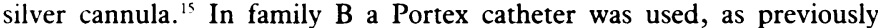
described. ${ }^{16}$ The chorionic villus sample was checked microscopically to exclude contamination with maternal decidua before incubation at $56^{\circ} \mathrm{C}$ for three hours in $250 \mu \mathrm{l} 0.075 \mathrm{M}$ sodium chloride and $0.025 \mathrm{M}$ edetic acid, 12.5 $\mu \mathrm{l} 10 \%$ sodium dodecylsulphate, and $10 \mu \mathrm{l}$ proteinase $\mathrm{K}$. This was followed by extractions with phenol, phenol plus chloroform, and finally twice with chloroform. The DNA was then precipitated with ethanol and reconstituted in $100 \mu \mathrm{TE}, \mathrm{pH} 8.0$ (10 mM TRIS (trometamol), $1 \mathrm{mM}$ edetic acid). The yield was about $2 \mu \mathrm{g} \mathrm{DNA} / \mathrm{mg}$ chorionic villus material.

DNA samples from all subjects were anaylsed for the BglII restriction fragment length polymorphism with the DX13 probe as follows: the DNA was digested with the restriction enzyme $\mathrm{Bg} \mathrm{lII}$; resulting fragments were separated by electrophoresis on a $0.8 \%$ agarose gel and transferred to nitrocellulose filters by Southern blotting. ${ }^{17}$ Subsequently, DNA bound to the filter, was hybridised with the DX13 probe labelled with phosphorus-32 by nick translation.

Hybridisation was performed overnight at $65^{\circ} \mathrm{C}$ in $0.1 \%$ sodium dodecylsulphate, four $\times \operatorname{SSC}(0.15 \mathrm{M}$ sodium chloride and $0.015 \mathrm{M}$ sodium citrate), $10 \times$ Denhardts $(0 \cdot 2 \% \mathrm{wt} / \mathrm{vol}$ bovine serum albumin, $0 \cdot 2 \% \mathrm{wt} / \mathrm{vol}$ povidone, and $0.2 \% \mathrm{wt} / \mathrm{vol}$ Ficoll 400$), 10 \mu \mathrm{g} /$ poly A/ml, $50 \mu \mathrm{g} /$ sonicated DNA from herring sperm $/ \mathrm{ml}, 7 \% \mathrm{wt} / \mathrm{vol}$ dextran sulphate, and $11 \mathrm{~Bq}(0 \cdot 3 \mu \mathrm{Ci})$ heat denatured probe $\mathrm{DX} 13 / \mathrm{ml}$.

After hybridisation excess probe was washed off in three $\times$ SSC in $0.1 \%$ sodium dodecylsulphate for 30 minutes at $23^{\circ} \mathrm{C}$ followed by one hour at $65^{\circ} \mathrm{C}$ in one $\times$ SSC in $0 \cdot 1 \%$ sodium dodecylsulphate. The DNA bands, hybridised to the ${ }^{32} \mathrm{P}$ labelled probe, were detected by autoradiography with $x$ ray film and intensifying screens.

Detection of DNA sequences specific to $\mathrm{Y}$ chromosomes was performed using the probe pHY $2 \cdot 1$, as previously reported. ${ }^{7}$ Samples of DNA $(1-2 \mu \mathrm{g})$ were digested with the restriction enzyme Hae III. The Southern blotting, hybridisation, and washing procedure after hybridisation were performed as in the analysis with the DX13 probe. Autoradiography took two to three hours, producing one major $2 \cdot 1 \mathrm{~kb}$ band, which was about 1000 times more intense in men than in women.

Previous studies with the DX13 probe have shown that half of normal women are heterozygous for the BglII restriction fragment length polymorphism, ${ }^{9}$ having both a $5 \cdot 8$ and a $2 \cdot 8 \mathrm{~kb}$ fragment (designated alleles 1 and 2). Studies of families with haemophilia have suggested close linkage between haemophilia A and DX13 with a maximum Lod score of 8.4 at a recombination fraction of $0 \cdot 0$ (95\% confidence limits $8 \%$; $90 \%$ confidence limits $6 \%$ ). Further data from studies that have used the factor VIII and DX13 probes in normal families give an additional Lod score of $7 \cdot 8$ with no recombination. ${ }^{11}$ Combining these two sets of data gives the $95 \%$ confidence limits of the recombination fraction as $0-4 \cdot 5 \%$.

Conventional tests to detect carriers-Assays of factor VIII:C and factor VIIIR:Ag were carried out, as described previously. ${ }^{18} \mathrm{~A}$ group of 32 obligate carriers and 31 healthy female controls was used to calculate a linear discriminant function that could be used to assign probabilities of carrier state to women at risk. ${ }^{19}$

Calculation of genetic risks was done by hand calculation, ${ }^{20}$ programmable calculators, ${ }^{21}$ and the computer programs Liped ${ }^{22} 23$ and Linkage. ${ }^{24}$

\section{Results}

FIRST TRIMESTER PRENATAL DIAGNOSIS

A woman, II-6, from family A (fig 1), which was known to the haemophilia centre and obstetric services, presented with her third pregnancy at seven weeks' gestation. Two male fetuses from previous pregnancies had been diagnosed as having severe factor VIII deficiency after samples of fetoscopic
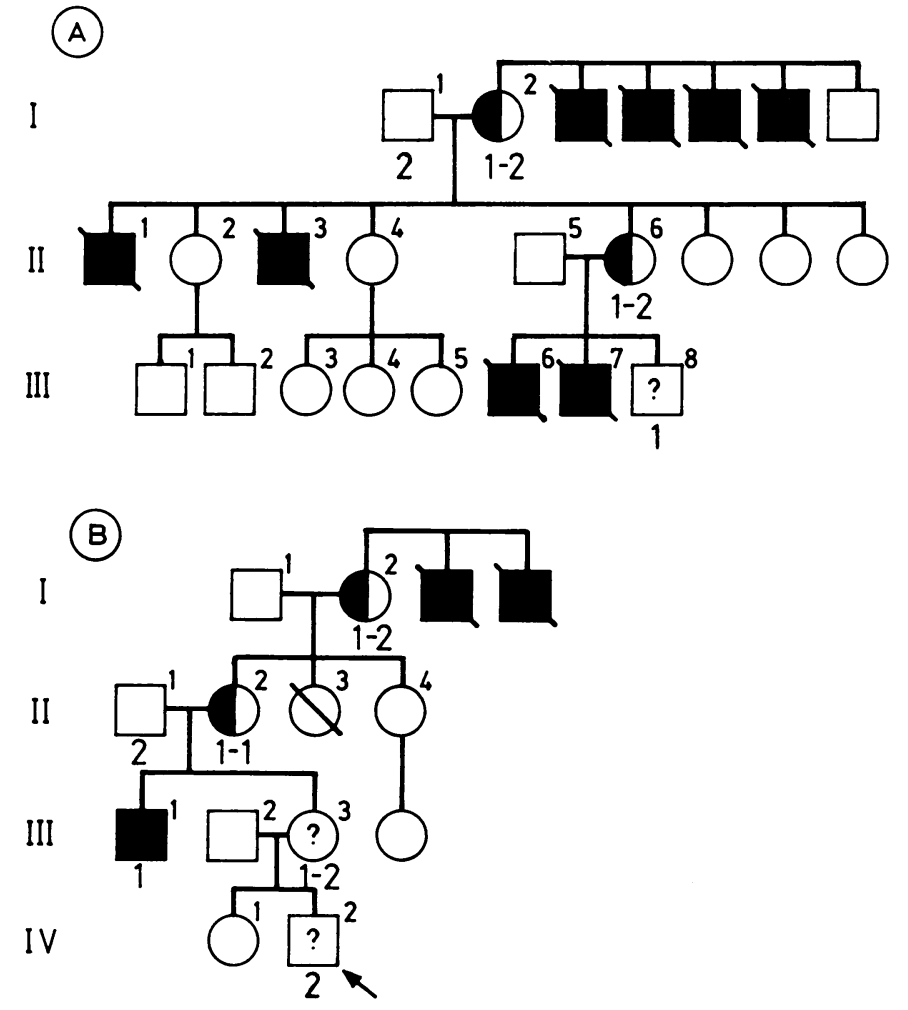

FIG 1-Pedigrees of families A and B.

blood had been examined at 18 weeks' gestation. In both cases the parents had opted for termination of the pregnancy. The pedigree indicates that this woman, II-6, had inherited the haemophilia mutation from her mother, I-2, who had had four brothers and two sons who had died from haemophilia.

Chorionic villus sampling was performed at 10 weeks' gestation, and about $20 \mathrm{mg}$ of material was obtained for analysis of DNA. Chorionic villus DNA hybridised strongly with the $\mathrm{Y}$ specific probe $\mathrm{pHY} 2 \cdot 1$, indicating that the fetus was male. Figure 1 shows the segregation of the alleles for the BGIII restriction fragment length polymorphism obtained by using the DX13 probe. The propositus, II-6, and her mother, I-2, were heterozygous, having both the $5.8 \mathrm{~kb}$ band (allele 1 ) and the $2.8 \mathrm{~kb}$ band (allele 2). The linkage phase between these alleles and the haemophilia mutation in the propositus could be established only by finding which allele she had received from her non-haemophilic father, I-1. His X chromosome carried allele 2 so his daughter must have inherited an $\mathrm{X}$ chromosome carrying both the haemophilia mutation and the restriction fragment length polymorphism allele 1 from her mother. It was this $\mathrm{X}$ chromosome that she had transmitted to her fetus, III-8, as analysis of chorionic villus DNA showed only a $5.8 \mathrm{~kb}$ band (allele 1). Excluding the unlikely event of a crossover between DX13 
and the haemophilia mutation or an erroneous assumption of the paternity of the woman, II-6, this result predicted that the fetus, III-8, was affected.

Comparison of 12 blood groups between the woman, II-6, and her parents showed no evidence of non-paternity. The parents were told the fetus had at least a $95 \%$ chance of being affected, and they opted for termination of pregnancy by vaginal aspiration at 12 weeks' gestation. Immediately before this procedure, with the mother's consent, a fetal blood sample was obtained by cardiac puncture under ultrasound guidance. This showed no factor VIII activity by the factor VIII:C antigen assay, ${ }^{25}$ thus confirming the diagnosis.

Family B (fig 1) was known to the haemophilia centre, where the propositus, III-3, had had conventional coagulation tests that had given her an overall probability of being a carrier of haemophilia A of $29 \%$. During her first pregnancy she had opted for determination of fetal sex by analysis of fetal chromosomes after amniocentesis at 16 weeks' gestation and fortunately, was carrying a girl, IV-1. She presented again during her second pregnancy at seven weeks' gestation, and blood samples for DNA analysis with the DX13 probe were obtained from her parents and haemophilic brother.

Her brother, III-1, had inherited allele 1 ( $5.8 \mathrm{~kb}$ band) together with the haemophilia mutation from his mother, II-2, who was homozygous for allele 1. As the mother was homozygous this restriction fragment length polymorphism could not be used to determine the carrier state in the propositus, III-3. Her father, II-1, however, carried allele 2 , and thus the propositus was heterozygous with the haemophilia mutation if she was a carrier, in linkage phase with allele 1 .

Chorionic villus sampling was performed at 8.5 weeks' gestation, and about $20 \mathrm{mg}$ of material was obtained for DNA analysis and fetal karyotyping. All results were available 10 days later. An insufficient number of good quality metaphase spreads was obtained to enable a complete karyotype analysis, but fluorescent $\mathrm{Y}$ chromosomes were observed in 15 metaphase spreads, indicating a male fetus. The DNA from the chorionic villus hybridised strongly with the $\mathrm{Y}$ specific probe ( $\mathrm{pHY} 2 \cdot 1)$, indicating male sex, and analysis with DX13 showed that the fetus had inherited allele 2 , the $\mathrm{X}$ chromosome that originally came from the non-haemophilic grandfather, II-1.

In this case errors could not arise from non-paternity, and incorrect prediction of the outcome depended on the chance of a crossover between DX 13 and the haemophilia loci. This had a $95 \%$ confidence limit of $5 \%$, and as any crossover would occur with an X chromosome that had a $29 \%$ chance of carrying the haemophilia mutation (from coagulation results) the overall chance of the fetus being affected was no greater than one in $60(0.05 \times 0.29=$ $0.0145 \%$ ).

The parents had to decide whether they wanted to take this low risk or seek confirmation by sampling of fetal blood at 18 weeks' gestation. Fortunately, before 18 weeks' gestation further gene tracking studies with the $\mathrm{BclI}$ restriction fragment length polymorphism detected by the gene

TABLE I-Risks of being a carrier of haemophilia A

\begin{tabular}{|c|c|c|c|c|}
\hline Family/subject & $\begin{array}{c}\text { From pedigree } \\
\text { alone }\end{array}$ & $\begin{array}{l}\text { Pedigree } \\
\text { + DX13 }\end{array}$ & $\begin{array}{c}\text { Pedigree }+ \\
\text { factor VIII assays }\end{array}$ & $\begin{array}{l}\text { Pedigree + } \\
\text { factor VIll assay } \\
+ \text { DX13 }\end{array}$ \\
\hline $\mathrm{C} / \mathrm{III}-1$ & 0.333 & 0.026 & & \\
\hline C.III-3 & 0.333 & 0.9 & & \\
\hline CIIII-5 & 0.333 & 0.026 & & \\
\hline D III-1 & 0.5 & 0.95 & 0.989 & 0.999 \\
\hline $\mathrm{E} / \mathrm{II}-\mathrm{I}^{*}$ & 0.5 & 0.052 & 0.044 & 0.0025 \\
\hline FIII-4 & 0.32 & 0.58 & & \\
\hline GIV-1 & 0.45 & 0.81 & 0.989 & 0.998 \\
\hline H III-1 & 0.5 & 0.95 & 0.76 & 0.984 \\
\hline $\mathrm{H} / \mathrm{III}-2$ & 0.5 & 0.05 & 0.995 & 0.91 \\
\hline
\end{tabular}

* $1-1$ is assumed to be a definite carrier.

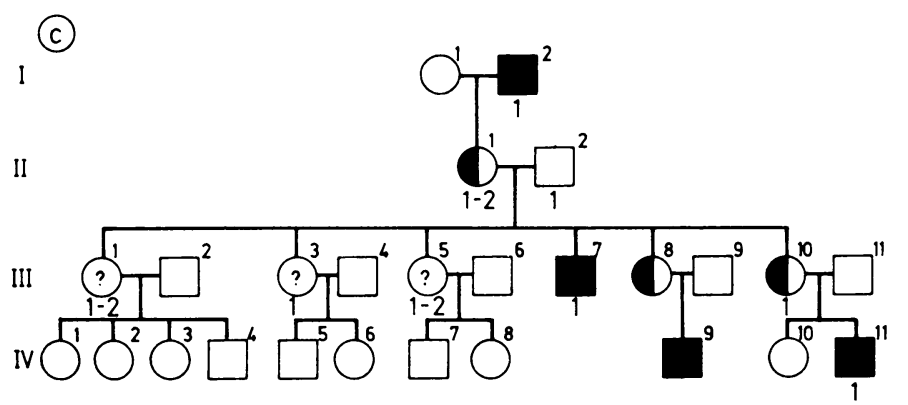

FIG 2-Pedigree of family C. specific factor VIII probe indicated that the propositus was not a carrier (E G D Tuddenham, personal communication), and no further prenatal tests were carried out.

\section{CARRIER DETECTION}

Of the 23 mothers tested, 14 were heterozygous for the DX13 probe-that is, the probe could be used to predict carrier state in their daughters. These mothers had a total of 26 daughters, of whom nine were tested.

To show the various factors that must be taken into account in estimating genetic risks the potential female carriers were classified according to the nature of the pedigree. These are described in detail below. Table I gives the risk values of being a carrier of haemophilia $\mathrm{A}$.

Linkage phase of mother of potential female carrier is known, DX13 probe used alone. Other pedigree information can be used (fig 2)

A woman, II-1, from family $\mathrm{C}$, is a double heterozygote for the haemophilia A gene mutation and the DX13 marker alleles. She received allele 1 at the marker locus from her affected father. She must therefore carry the haemophilia A gene on the same X chromosome as allele 1 at the marker locus and her linkage phase is therefore known. Two daughters have affected sons and are obligate carriers. Three other daughters each have a normal son and are potential carriers. Daughter III-1 must have received marker allele 2 from her mother. This means that she can carry the haemophilia A gene only if a crossover has occurred between the haemophilia $A$ and marker locus. As she has a normal son the chance of being a carrier is lowered.

TABLE II-Calculation of risks, pedigree C

\begin{tabular}{|c|c|c|}
\hline & \multicolumn{2}{|c|}{$\begin{array}{c}\text { Genotype of woman, III-1, at } \\
\text { haemophilia A locus }\end{array}$} \\
\hline & Carrier & Non-carrier \\
\hline Prior probability & 0.5 & $0 \cdot 5$ \\
\hline $\begin{array}{l}\text { Condinonal probabinties: } \\
\text { Of DX } 13 \text { allele }\end{array}$ & 0.05 & 0.95 \\
\hline Of normal son & & \\
\hline Joint probability & 0.0125 & 0.475 \\
\hline
\end{tabular}

The final probability of her being a carrier, calculated from Bayes's formula assuming a recombination fraction of $5 \%$ (table II), is one in 39 . Similar calculations may be made for the other daughters.

Mother of potential carriers is a phase known double heterozygote. Conventional tests to detect carriers are available (fig 3 )

In family $\mathrm{D}$ the mother, II-1, is also a phase known double heterozygote. Her daughter, III- 1 has received the same marker allele 2 as her affected brothers. Results of conventional carrier detection tests in the daughter suggest that she has a 91:1 chance of being a carrier. These data can be combined using Bayes's formula to give a final probability of $(0.95 \times 91) /$ $[(0.95 \times 91)+(0.05 \times 1)]=0.999$

Linkage phase of mother of potential carrier is unknown. Conventional tests to detect carriers are available.

In family $\mathrm{E}$ (fig 3 ) the mother I-1 is highly likely to be a carrier for the haemophilia A gene as she has one affected son and factor VIII studies yielded very abnormal results. She is also heterozygous at the DX13 locus. Her parents were not available for study, however, so her linkage phase is unknown. Her linkage phase can be inferred from her affected son, who has received allele 2 , and her normal son, who has received allele 1 at the marker locus. Nevertheless, because of the small chance of two crossovers having occurred, there is a small possibility of error Exact calculation by hand of linkage phase using information from the sons and estimation of carrier state of the daughter, II-1, is complex, ${ }^{22}$ but computer programs may be used.$^{24} 25$ In this case the probability of the daughter, II-1, being a carrier is 0.052 (one in 19) from marker studies alone and 0.0025 (one in 400) when these studies are combined with conventional carrier tests. 
The last two examples emphasise that the use of conventional tests to detect carriers, together with the DX13 probe, can provide precise information on carrier state.
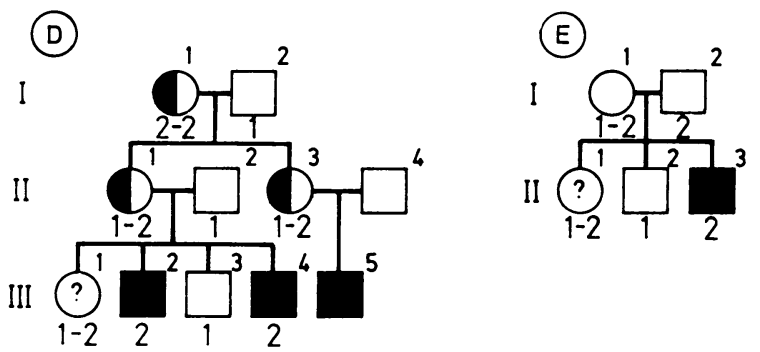

FIG 3-Pedigrees of families D and E.

Mother of potential carrier is linkage phase unknown and may have given rise to a new mutation (fig 4)

In families $F$ and $G$ the mother of the potential carrier has one affected son, although there is no family history of haemophilia. She could carry the haemophilia A gene or, alternatively, the affected boy could have arisen as a new mutation, in which case the mother would not be a carrier. Estimation of risks is complex and depends on the number and relationship of normal men in the pedigree, assumptions about the genetic fitness of affected men, and the ratio of new mutations in sperm and $\operatorname{ova}^{20}$ as well as on information
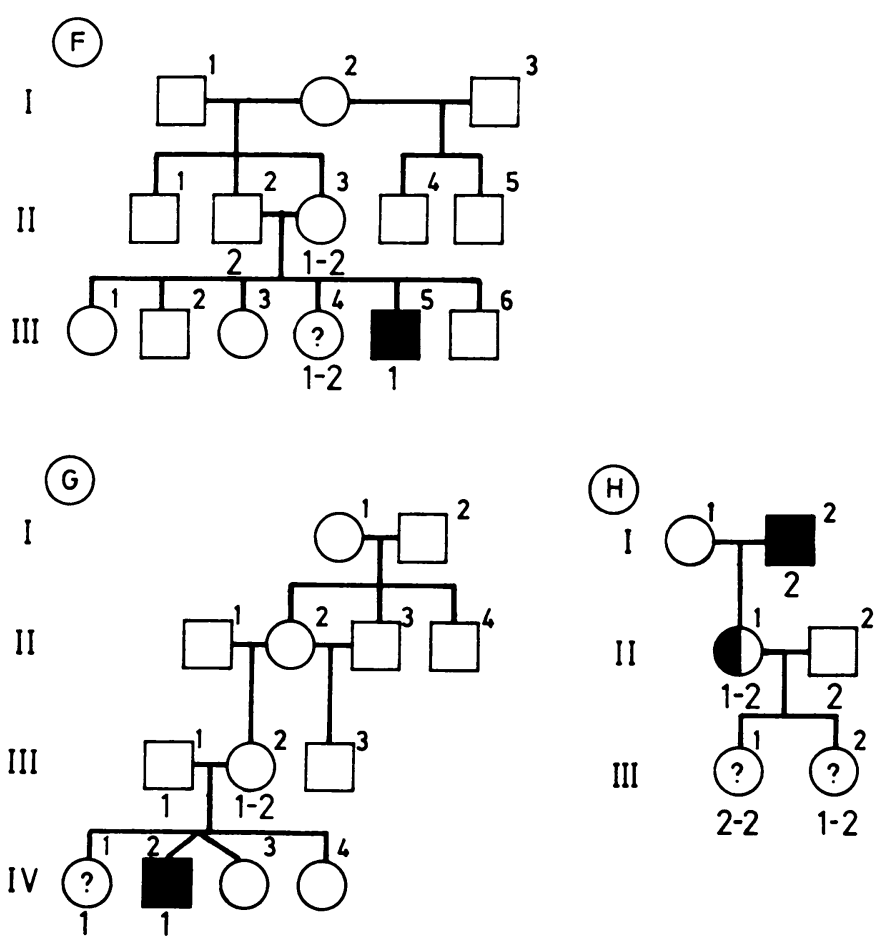

FIG 4 Pedigrees of families F, G, and $\mathbf{H}$.

from marker studies and conventional tests to detect carriers. In these two examples a genetic fitness of affected men of $70 \%$ and a sperm to ovum mutation rate of nine were assumed. Again, computer programs are necessary in all but the simplest cases.

In family F, although daughter III-4 has received the same marker allele as her affected brother, her chance of being a carrier, based on data on pedigree and DX13 alone, is 0.58 . This is because her brother could have received a new mutation and the linkage phase of her mother is unknown. Similar uncertainty is encountered in the calculation of the risks for daughter IV-1 in family $\mathrm{G}$ when using data on DX13 alone. The combined use of factor VIII assays, however, strongly suggests that she is a carrier.

\section{Data on linkage conflict with results from coagulation tests}

A woman, II-1, from family $\mathrm{H}$ (fig 4 ) is heterozygous at the DX13 and haemophilia A loci. Furthermore, she has received the haemophilia A gene on the same $\mathrm{X}$ chromosome as allele 2 from her father. Thus the normal allele at the factor VIII:C locus is on the same $\mathrm{X}$ chromosome as allele 1 , and her linkage phase is therefore known. The daughter III-1 has received allele 2 from her mother. If there has been no crossover daughter III-1 must carry the haemophilia A gene. A $95 \%$ risk is given because of the chance of a crossover. Daughter III-2 has received marker allele 1 from her mother and has a $5 \%$ chance of carrying the haemophilia A gene.

When the results from coagulation studies are considered, however, although for daughter III-1 they are compatible with her being a carrier for haemophilia $\mathrm{A}$, for daughter III-2 they are not compatible with the prediction that she is not a carrier. The results from coagulation studies were repeated in daughter III- 2 and indicated the strong possibility of a crossover between the DX13 and haemophilia A loci.

It is possible in this family to show that a crossover occurred by the use of BclI polymorphism within the factor VIII probe itself. This suggests that both daughters, III-1 and III-2, inherited the abnormal gene at the haemophilia A locus. It is necessary to test the father, II-2, to discover which marker allele daughter III-2 received from her mother, and non-paternity could also explain the conflicting results. In this family blood groups and results of HLA testing made non-paternity extremely unlikely, and, therefore, this may represent the first observed crossover between the factor VIII:C locus and DX13.

\section{Discussion}

The above examples show several important points in the prenatal diagnosis and estimation of carrier state for haemophilia $\mathrm{A}$ using linked DNA probes. Members of the family other than the fetus or subject at risk must be tested-that is, the mother and affected and unaffected brothers as well as the maternal grandparents, if possible, and the father. The possibility of non-paternity must always be considered when interpreting the results. In certain cases correct prediction of the haemophilia A genotype requires knowledge of the marker type in the true father. In these cases testing for paternity by either conventional techniques or newer DNA techniques ${ }^{26}$ is essential.

Only a proportion of female carriers will be heterozygous at the marker locus-that is, their two $\mathrm{X}$ chromosomes are different for this marker. If the mother of a potentially affected fetus or female carrier is not heterozygous (in about half of the cases with DX13) the probe cannot be used to predict the haemophilia A genotype.

The accuracy of predictions depends on the proximity of the DNA probe to the disease locus on the $\mathrm{X}$ chromosome. This can be estimated only from family data and will have specific confidence limits. In this study a conservative estimate of the genetic distance (or recombination fraction) was used. This corresponded to the $95 \%$ confidence limits of the recombination fraction-that is, $5 \%$.

Conventional tests to detect carriers may greatly improve the estimation of risk if combined with data obtained from DNA probes. This is especially true when there may be a new mutation at the disease locus. This was shown in families $F$ and $G$ in the study to detect carriers.

Estimation of risks from pedigree, DNA, and carrier detection data can be straightforward but becomes much more complex if the linkage phases of key women in the pedigree are unknown or if there is a possibility of a new mutation at the disease locus. In this case computer programs should be used to estimate risks, and assumptions about unknown genetic variables may have to be made: caution and special skill are necessary.

In future the use of polymorphisms in the factor VIII gene ${ }^{11}$ will enable most families to be helped by gene tracking. The need for studies of families and testing of paternity in some cases will, of course, remain, although the risk of a wrong prediction due to crossovers will be reduced to virtually zero. Gene tracking studies using linked DNA probes can, however, provide an alternative means of early prenatal diagnosis and greatly improve the prediction of carrier states for haemophilia $\mathrm{A}$ in a proportion of families in which the factor VIII probe is not informative. Other closely linked probes are also available. ${ }^{27}$

The introduction of linked DNA probes into clinical practice 
requires close collaboration and an effective referral system among haemophilia centres, obstetricians, and genetic centres offering DNA analysis. The fairly rapid introduction of first trimester prenatal diagnosis using the DX13 probe has been helped by the availability of the well established method of prenatal diagnosis by fetal blood sampling at 18 weeks' gestation, which provides an alternative back up when data on families are not informative.

We thank all the staff of the Hospital for Sick Children, Great Ormond Street, and Royal Free Hospital haemophilia centres; Sister Caroline Tubridy for home visits; Dr K L Rogers, South London Transfusion Centre, for blood grouping; Dr Frances Rotblat, Royal Free Hospital, for the fetal VIII:C antigen assay; and Mrs Melanie Barham for administrative and secretarial help. $\mathrm{KH}$ is supported by a grant from Action Research for the Crippled Child. RCW is supported by a Medical Research Council grant, and RJAP is supported by grants from the National Birthday Trust, the Sir Halley Stewart Trust, and the Katherine Bishop Harman award 1983.

\section{References}

1 Carter CO. Monogenic disorders. I Med Genet 1977;14:316-20.

2 Colman RW, Hirsh J, Marder VJ, Salzman EW, eds. Hemostasis and thrombosis. Basic principles and clinical practice. Philadelphia: Lippincott, 1982:76.

3 Spakes RS, Berg C, Evans HJ, Klinger HP, eds. Human gene mapping 7 (1984): seventh workshop on human gene mapping. Cytogenet Cell Genet 1984;37:1-4.

4 Graham JB. Genotype assignment (carrier detection) in the haemophilias. Clinical Haematology 1979;8:115-45.

5 Mibashan RS, Rodeck CH, Thumpston JK, et al. Plasma assay of fetal factor VIIIC and IX for prenatal diagnosis of haemophilia. Lancet 1979; i: 1309.

6 Simoni G, Brambati B, Danesino C, Rossella F, Terzoli GL, Fraccaro M. Hum Genet 1983;63: 349-57.

7 Gosden JR, Mitchell AR, Gosden CM, Rodeck CH, Morsman JM. Direct vision chorion biopsy and chromosome-specific probes for determination of fetal sex in first trimester prenatal diagnosis. Lancet 1982; ii: 1416-9.

8 Williamson R, Eskdale J, Coleman DV, Niazi M, Loeffler FE, Modell BM. Direct gene analysis of chorionic villi: a possible technique for first-trimester antenatal diagnosis of haemoglobinopathies. Lancet 1981;ii:1125-7.

9 Harper K, Winter RM, Pembrey ME, Hartley D, Davies KE, Tuddenham EGD. A clinically useful DNA probe closely linked to haemophilia A. Lancet 1984;ii:6-8.

10 Gitschier J, Wood WI, Goralka TM, et al. Characterization of the human factor VIII gene. Nature 1984;312:326-30

11 Gitschier J, Drayna D, Tuddenham EGD, White RL, Lawn RM. Genetic mapping and diagnosis of haemophilia $\mathrm{A}$ achieved through a Bcll polymorphism in the factor VIII gene. Nature of haemophilia A

12 Gitschier J, Lawn RM, Rotblat F, Goldman E, Tuddenham EGD. Antenatal diagnosis and carrier detection of haemophilia A using factor VIII gene probe. Lancet $1985 ; \mathrm{i}: 1093-4$.

13 Antonarakiss S, Copeland KL, Carpenter RJ, et al. Prenatal diagnosis of haemophilia A by factor VIII gene analysis. Lancet 1985 ; $1: 1407-9$.

14 Kunkel LM, Smith KD, Boyer SH, et al. Analysis of human Y-chromosome specific reiterated DNA in chromosome variants. Proc Natl Acad Sci USA 1977;74:1245-9.

15 Rodeck CH, Morsman JM, Nicolaides KH, McKenzie C, Gosden CM, Gosden JR. A singleoperator technique for first trimester chorion biopsy. Lancet 1983;ii:1340-1.

16 Ward RHT, Modell B, Petrou M, Karagozlou F, Douratsos E. Method of sampling chorionic villi in the first trimester of pregnancy under the guidance of real time ultrasound. $\mathrm{Br} \mathrm{Med} J$ 1983;286:1542-4.

17 Southern E. Detection of specific sequences among DNA fragments separated by gel electrophoresis. F Mol Biol 1975;98:503-17.

18 Winter RM, Tuddenham EGD, Goldman E, Matthews KB. A maximum likelihood estimate of the sex ratio of mutation rates in haemophilia A. Hum Genet 1984;64:156-9.

19 Akhmeteli MA, Aledort LM, Alexiants S, et al. Methods for the detection of haemophilia carriers: a memorandum. Bull WHO 1977;55:675-702.

20 Pembrey ME, Davies KE, Winter RM, et al. Clinical use of DNA markers linked to the gene for Duchenne muscular dystrophy. Arch Dis Child 1984:59:208-16.

21 Winter RM. The calculation of genetic risks in X-linked recessive conditions using programmable calculators. Clin Genet 1980;17:171-5.

$22 \mathrm{Ott} \mathrm{J}$. Estimation of the recombination fraction in human pedigrees: efficient computation of the likelihood for human linkage studies. Am $\mathcal{F}$ Hum Genet 1974;26:588-97.

23 Price RA, Kidd KK. Utilising automated methods to improve estimates of recurrence risk with linked genetic markers. Am J Med Genet 1984;17:621-5.

24 Lathrop GM, Lalouel JM. Easy calculations of Lod scores and genetic risks on small computers. Am F Hum Genet 1984;36:460-5.

25 Rotblat F, Tuddenham EGD. Immunologic studies of factor VIII coagulant activity. I. Assays based on a haemophilic and an acquired antibody to VIIIC. Thromb Res 1981;21:431-45.

26 Jeffreys AJ, Wilson V, Thein SL. Hypervariable "minisatellite" regions in human DNA. Nature 1985;314:67-73.

27 Oberie I, Camerino G, Heilig R, et al. Genetic screening for hemophilia A (classic hemophilia) with a polymorphic DNA probe. $N$ Engl f Med 1985;312:682-6.

(Accepted 23 fuly 1985)

\title{
Small bowel biopsy for malabsorption: comparison of the diagnostic adequacy of endoscopic forceps and capsule biopsy specimens
}

\author{
A S MEE, MARGARET BURKE, A G VALLON, J NEWMAN, P B COTTON
}

\begin{abstract}
Biopsy specimens of the small bowel were obtained from $\mathbf{4 0}$ patients suspected of having malabsorption. Four different techniques were used at a single session-namely, endoscopic biopsy of the descending duodenum using paediatric and standard size forceps and suction capsule biopsy of the descending duodenum and the proximal jejunum. Specimens were compared for size, adequacy, and ability to confirm or exclude mucosal abnormality. Fourteen patients had villous atrophy. In all patients four biopsy specimens were obtained with paediatric endoscopic forceps and four with standard endoscopic forceps. No capsule
\end{abstract}

Department of Gastroenterology and Bland Sutton Institute of Pathology, Middlesex Hospital and Medical School, London W1N 8AA

A S MEE, MD, MRCP, senior registrar

MARGARET BURKE, MRCPATH, lecturer

A G VALLON, MB, MRCP, honorary senior registrar

J NEWMAN, MRCPATH, senior lecturer

P B COTTON, MD, FRCP, consultant physician

Correspondence to: Dr A S Mee, Battle Hospital, Reading, Berks RG3 IAG. biopsy specimen was retrieved from the duodenum in three patients and from the jejunum in five patients. Specimens were considered to be adequate in 36 patients when paediatric forceps were used, in 39 when standard forceps were used, in 28 on duodenal capsule biopsy, and in 32 on jejunal capsule biopsy.

This study indicates that the most reliable method for diagnosing or excluding villous atrophy is endoscopic forceps biopsy of the descending duodenum, provided that at least four specimens are obtained with standard size forceps.

\section{Introduction}

Mucosal biopsy of the small intestine is an essential investigation in patients suspected of having diffuse disease of the small bowel. The most common indication for biopsy is to confirm (or refute) a diagnosis of gluten sensitive enteropathy and to monitor the mucosal response to exclusion of gluten.

The suction biopsy capsule is widely used' to provide specimens from the proximal jejunum that are large enough for correct orientation, histological interpretation, and biochemical study. ${ }^{2}$ Nevertheless, the method has disadvantages. The need for radiological screening makes it unsuitable for repeated use in young 